\title{
A Pine with Six Hands
}

https://doi.org/10.51897/interalia/IWNP4838

\section{Liliana Piskorska}

On a broad stretch of lowlands striated by the blue threads of rivers, there was a city all in gold. And in the city, there was a hill of piled up rubble, and on the hill there grew a pine, and on the pine there were six hands.

And the hill is immense, the top invisible behind the clouds; it rises sharply into the sky, and on all its slopes, there is a black forest. Huge oaks, pines, beeches, firs - one growing upon the others. A tree jutting over another tree, higher and higher. Between them, on the ground, a thicket of thorns, hawthorn and poisonous herbs. A rubble of huge rocks, all green with wet moss, and among them the pine. She stands tall and has six branches like six green hands, and one of them strange, magical.

The forest differs in no respect from a thousand others, on other hills across the world. And the pine seems the same, no different from a thousand other pines.

From the very top of the hill you can see the entire horizon of the land - mountains, fields, forests, and waters. Villages, great ironworks, houses, factories, and little towns. So many that you cannot count them all. And they lie like a painted picture, so marvelous that you could look at it for a hundred years and still not have enough.

The dawn was rising.

At the bottom of the hill it was still a dark morning. The entire town was still asleep. The gold had not yet begun goldening, the windows of human houses were not yet touched by a sun ray.

From the very top of the hill the light went down the forest slopes. The shine was smoky and rainhazy, it did not light up the features of the landscape but separated them from each other. It settled on the backs of the trees like golden dust.

On the low grass, mowed to a crew-cut, a pine stood, branching out and humming with her six handlike branches towards the approaching sun.

Which will be the first, which the first, the first hand to be touched by a ray of light?

The pine stood - literally - for it seemed that she ended at the very point where her trunk touched the grass. She ended, and almost without putting her roots down in the soil, with the very basis of her 
trunk, wider at her bottom, she grounded herself and found her balance on the ground. For where was the pine supposed to put down its roots if there was almost no soil underneath her. Not much, only a little dirt, and underneath - debris. Only as much as a pine can make with her sister pines in a hundred years, mold from their needles mixed with fallen leaves.

So the pine stood on six roots which, like the arms of a star, protruded in six directions of the world. Pushing slowly yet persistently through the debris of the ruined city, which formed the hill.

And although people assume that we all know what a tree is. We have to remember that we always see only half of the tree. The other half is only ever imagined. And often we cannot imagine this mysteriousness at all; in our proud knowledge we think that where our sight cannot reach, there is nothing to look for.

And there were so many things in the hill.

A multitude of debris. Red bricks, concrete, dust, ceiling beams. Shattered tombstones of marble, terrazzo, and granite. Household trash which fell apart together with the demolished houses. All those human belongings which no-one grabbed when forced to run. Whatever people couldn't take on their backs, in small carts, grab, take, carry to a new home. And paving stones taken from a field long ago, crumbs of churches, a synagogue, a chapel. Even fragments of monuments, metals, old nails and rust.

And the pine roots penetrate all this as they spread outwards. When a root meets a piece of debris, it touches its song, embraces it, and caresses it in a debris embrace.

The dawn was rising.

Like lightning, its song carried by the sap flows upwards from the roots, higher and higher. Through debris and dust, through shallow soil, it flows in the pine trunk through the pine body. Higher and higher, until it reaches the pine hand-branch. The soft needles of the sun touch the first pine hand and melt within in it, spreading sunlight, yellow and red.

The tree hummed louder. The hand reached out, purred, and started to sing in a tree voice. And in the voice, these words could be heard:

\section{The First Story: On How the Countess Arrives in Breslau}

Open the shutters, let in some air

Sweep the dust from the floor, Let's let some light in the room

When the world once more starts making sense

Alert the dust pail and broom 
If it all goes as planned our time may be at hand any day now

Sweep up the years, the sadness and tears and throw them away

Once upon a time, shortly before All Saints' Day, a certain elegant and particularly stylish countess arrived in Breslau with her fiancé. Her name was Dina. It was love that brought the countess to Breslau, as several months earlier in faraway Paris she had met a humble German teacher who had come to the French capital to learn languages. They met and fell in love like two innocent doves.

Driven by the hope of true love, the countess follows the teacher to his home city.

The wedding is set to happen in three months' time.

She spends her first days at the Hotel du Nord. She has come to the city without a friend, not even a maid, and it is not proper for a young lady of high birth to live alone. Thus, she decides to rent a place, two rooms at most.

A rented carriage comes from the hotel; inside it, luggage, the coffers of an elegant lady. So many things: expensive silk gowns, for daily wear, morning gowns, evening ones. Some red, some in completely different colors. (One of them Dina puts on while still at the Hotel du Nord. When she descends the staircase, the waiters say of her: "Here comes Queen Louise.") Then a long silk shawl, a pink petticoat, Parisian hats, a whole collection of shoes. Pictures and Venetian lamps, dressing accessories, an ivory fan. And everything with the engraved initials A.P. and a coat of arms, a crown with seven spikes. Then two men's suits (she says she only wears them during the carnival), a dagger whose hilt is studded with pearls.

Then a wrap which the countess ceremoniously shows to her landlady. (A souvenir of my late mother, sewn by slaves.) The landlady admires the wrap. She has never seen anything like it.

And this is her portrait - Dina says, putting the framed daguerreotype on the chest of drawers under the window.

The countess moves in and decides to rearrange the furniture. Everything is to be painted pink. A wallpaper man arrives, the furniture is sent to an upholsterer and returns all velvety pink. She decorates the chandelier on her own. (She's always been one for feminine pursuits.) She orders Parisian lace curtains for 75 franks. There are flowers everywhere on new tables.

Dina rests her shoulder against the pink walls and asks her fiancé if the color suits her. She calls him tenderly "Schatz" - darling. 
One evening she sits down with the landlady and tells her story. Her name is Alma Dina de Paradeida and she is the daughter of a Spanish consul posted to Brazil.

Her name is Alma Dina de Paradeida and she was born in Rio de Janeiro, as a child of a German doctor and a Brazilian woman.

Her name is Alma Dina de Paradeida and her stepfather is a German doctor from the Berlin area.

Oh, she has lived through so much. She has traversed the ocean nine times, two times her ship almost got wrecked, two gentlemen shot themselves, and three ladies went insane.

Another time, there was to be a great masked ball, and Dina decided to prepare paper flowers for all the elegant ladies. For three days, she sits in her cabin and has no time to prepare something for herself. One of the gentlemen comes to get her and wants to escort her to the ballroom, but Dina says she has no costume. The gentleman comes up with the idea of dressing her as a Neapolitan and lends her his own son's clothes. Dina puts them on quickly. When she appears on the top deck, nobody recognizes her. Everyone wonders why the countess hasn't come. Finally, she speaks from among the guests: "Don't you recognize me?" - she tells her landlady, laughing.

This is how the weeks go by.

The fiancé comes to visit every Sunday and Wednesday, as it should be. She very rarely leaves the apartment. (Later they will write that their contact was formal and that Dina tended to be pathologically jealous.)

On the day the fiancée is to be introduced to her groom's family, she starts getting ready at six and it takes her in an hour and a half. She wears a dress of Irish embroidery, and her corset is laced so tightly that has trouble breathing and coughs. (Later they write that her waist was 52 centimeters. And that women will appreciate the meaning of these numbers.)

She apologizes for coughing. The fiancé doesn't let anything on, but the landlady notices that he is embarrassed by this situation. Everyone has already arrived. The entire family with over a dozen children. Dina is close to fainting, she rests her head against the fiancé's shoulder, a tear streaks down her cheek.

And yet, everything is as it should be. The men kiss Dina's hand, women curtsy to her. They sit at the table, wine is served, and the head of the family welcomes the countess to her new family. Afterwards, the betrothed exchange engagement rings and everyone kisses each other. 
Dina coughs, and the women look at her surprised, because the cough does not sound at all like it should. Then the six-year-old son of her fiancé's sister cries out loud, looking at her. He says that the countess is not who he clearly knows she is.

And the dawn was still rising.

Like lightning, its song carried by the sap flows upwards from the roots, higher and higher. Through debris and dust, through shallow soil, it flows in the pine trunk through the pine body. Higher and higher, until it reaches the pine hand-branch. The soft needles of the sun touch the pine's second hand and melt within in it, spreading sunlight, yellow and red.

The tree hummed louder. The hand reached out, purred, and started to sing in a tree voice. And in the voice, these words could be heard:

\section{The Second Story: On the Balls in Berlin}

From the late evening hours until the new day

We walk along Friedrichstrasse as always,

Arm in arm. There and back again. One foot after the other.

We walk, smartly dressed as always.

Modesty is not good for business.

This is the boys' first rule: always be fashionable and elegant.

And the second rule is being calm and saying no sometimes.

Never shyly, never with restraint.

And finally, if you want to get rich,

The third rule is blackmail.

This happened in the great city of Berlin at the beginning of the previous century, in times which hardly anybody remembers. There are various cities in the world, and there are various countries and people living in them. But you won't find a city like Berlin in the whole wide world.

It is known for entertainments you cannot experience anywhere else. (If you know who to ask and if you know who you want to meet.)

From autumn to spring, even several times a week, balls were organized. Huge ones, for a thousand people or more. You need to pay a lot (it is said). But the experience is worth every mark?

Important visitors and sometimes even foreign travelers who wish to see something exceptional (if they know who to ask and they know who they want to meet) are led by the mighty of the city to one of the balls. 
At this time, there lived a certain man in the city of Berlin. He was already middle-aged, but still vigorous. A well-known doctor, a world-famous specialist, whose name has been recorded in the annals of history. And that name was Magnus Hirschfeld.

The doctor decides to attend the ball, the famous first ball of the year, which always takes place on the first Saturday after January the first. The year is 1903.

When the doctor enters the ballroom, he sees a blindingly lit space. Although as many as 800 people are expected, at 10 PM there is not a soul there, and the light shivers, as if in anticipation. Long minutes pass and suddenly the doors come alive.

Like a string of precious pearls, a colorful human crowd pours out of cabs and carriages. Some in evening wear, some in everyday clothes, and some wearing costumes from every possible era. Some come wearing rainbow colors, others - ballroom gowns. (At many of the balls women are few and far between, but there are balls held for them alone.) They come with masked faces and the doctor can only guess what kinds of faces gaze in his direction.

He looks at a Rococo noble woman who is helping her lady leave the carriage. Behind them there walks a fat Franciscan, after him a sailor, a baker, a clown, and a farmhand. Then a Pierrot, ladies in riding attire, a Japanese man, an officer, then a small geisha. A Carmen with burning eyes looks at a jockey, a fiery Italian deeply befriends a snowman.

At one of the balls the doctor meets Fraulein Katharina, the first woman in Berlin to be permitted to wear men's clothing at home, at work (and even in the street).

They come and go and nobody even knows who they are. Some give the impression of being so feminine in their appearance and moves that they look like birds of paradise. The doctor thinks some of them look inappropriate. Instead of masks they sport black mustaches smudged across their faces.

And police are already waiting inside. They have taken off their uniforms to merge with the crowd and make sure that no vile thing happens. But allegedly so far they have had no reason to intervene. The organizers have made sure that only the right people find their way to the ball.

The doctor's gaze is arrested by a lady in a Parisian evening gown. Later he learns that this was the countess Dina - a noblewoman recently arrived from Paris, who several years later would make newspaper headlines - counterfeit fiancée from Breslau, männliche Braut - they would scream in bold font.

It is said that the countess has a very elegant house in Berlin. She entertains guests and soon becomes well known in respectable society. 
Only some ladies have the kind of appeal that wins over other people, and Dina is one of those ladies. Some do it by means of money. Others by means of feminine charm.

And she has both.

At one in the morning, the ball reaches its peak. Afterwards there is a coffee break. And then the crowds arrive.

The servants pull out long tables and the show begins: singing, dancing, everything performed by the Damen-imitatoren of Berlin. (Dina also performs at the balls, she is a star for almost two years.) From the adjoining rooms one can hear bright laughter, the clinking of glass, and singing. No inappropriate sound disturbs the joy, until the moment when the last participants leave the ball in the light of winter dawn.

And the dawn kept rising.

Like lightning, its song carried by the sap flows upwards from the roots, higher and higher. Through debris and dust, through shallow soil, it flows in the pine trunk through the pine body. Higher and higher, until it reaches the pine hand-branch. The soft needles of the sun touch the pine's third hand and melt within in it, spreading sunlight, yellow and red.

The tree hummed louder. The hand reached out, purred, and started to sing in a tree voice. And in the voice, these words could be heard:

\section{The Third Story: On the Countess's Childhood}

When Dina was just six years old, she had a friend. A gardener's child, living two steps away from her family home. When she wanted to visit him, she had to walk over a footbridge which separated their abodes. In secret, she always brought him the most beautiful fruit from the kitchen table.

One day, when she wanted to run across the footbridge to her friend's house, there were two lizards basking there, all golden in sunlight. And it seemed to her that she saw two enormous dragons guarding the bridge and preventing her from crossing it. The terrified child knelt down and started praying that God send away the monsters. And in return, she would never steal fruit from the table.

She prays for hours at the footbridge, but her God does not take the reptiles away. Suddenly, she hears someone calling "Comtessine" - Little Countess! It is her governess calling. Behind her, a gardener runs and carries her home in his arms. Dina cannot walk, and the next day, she runs a high fever.

When Dina was still a child, her papa invented liquid soap. He does so as a gift to her mama, who takes good care of her skin. The soap is successful and they start to produce it on a mass scale. When 
the father dies, the business becomes a joint-stock company. (In America, one can still see these small bottles.)

She remembers well the day he died. Dina was in the living room with some friends of the house and someone asked whether the servants should wear white or black stockings. Suddenly, a cleaning woman entered the room and said, terrified, white as death: Please do not be scared, but the master has fallen very ill.

When Dina is fifteen, she often goes to the seaside. When there's a storm she enjoys testing the power of her voice and tries to shout louder than the waves. Since there are no other houses nearby, she and her mother can swim in the sea as if it belonged to them alone. Her mother warns her to only swim at certain times, but one day Dina ignores the warning, swims out into the sea and sees a giant wave rolling towards her. She begins to pray and thinks that she will never see her mother again, but the wave sweeps her back onto the beach. Dina interprets this as God's warning and decides never to affront fate again.

When Dina is seventeen, she spends several months in a sanatorium. For days, she makes roses out of silk paper. Her flowers always have to be faultless. Once, she makes a stem of paper chrysanthemums especially for her mama, who keeps them in a spot of honor for five years because they are so beautiful.

And the dawn kept rising.

Like lightning, its song carried by the sap flows upwards from the roots, higher and higher. Through debris and dust, through shallow soil, it flows in the pine trunk through the pine body. Higher and higher, until it reaches the pine hand-branch. The soft needles of the sun touch the pine's fourth hand and melt within in it, spreading sunlight, yellow and red.

The tree hummed louder. The hand reached out, purred, and started to sing in a tree voice. And in the voice, these words could be heard:

\section{The Fourth Story: On the Book Burning}

Several years later, in the great city of Berlin a scandal takes place and the mighty of the city change their minds. It turns out that the court of Kaiser Wilhelm had been attending the balls. That allegedly the people appearing there were too important. Names are named, insinuations made. Trials begin, one after the other.

From then on, the balls are banned. Yet nobody can point out the law that causes this to happen. Something is changing. The air smells different and nothing is as it was before. 
The doctor remembers meeting one of the old German counts on Unter den Linden. Asked how he is doing, the count, crushed, responds that unfortunately not well at all. For a moment, the doctor suspects that the count may have fallen into the hands of blackmailers, but there turns out to be a different reason. The count had a wonderful dress made by the best Parisian couturier, and now it hangs, unused, in the closet. By the time the dress arrived from the far away Paris, the balls had already been outlawed. It is said they will never happen again.

Twenty-seven years later, on May $6^{\text {th }}$, about 9.30 in the morning over a hundred students arrive in trucks in front of the Institute directed by the doctor. It is a spacious villa, quite close to the Reichstag. It is said that the building is almost empty. There are only a few employees left. The doctor escaped the country several months prior. They jump out of the trucks and run inside. They break down the doors. Behind them, there comes a brass orchestra, accompanying the students.

First they burst into the library which houses over twenty thousand volumes. They carry a list and systematically, shelf after shelf, book after book, they take the texts from the list off the shelves. They carry the heavy armloads of books down to the cars. Then they come back deal with what is on the walls. They tear down paintings, photographs, and posters. They break cabinets with exhibits. They work persistently. Altogether 5 thousand items - an impressive collection brought together from Europe and beyond, through the efforts of many people.

They finish their work at noon. They gather in front of the building. More and more onlookers join the crowd. Someone gives a speech and then the orchestra starts to play and they sing together.

Raise the flag! The ranks tightly closed!

The SA marches with calm, steady step.

Comrades shot by the Red Front and reactionaries

March in spirit within our ranks.

Clear the streets for the brown battalions,

Clear the streets for the storm division!

Millions are looking upon the swastika full of hope,

The day of freedom and of bread dawns!

For the last time, the call to arms is sounded!

For the fight, we all stand prepared! (...)

The time of bondage will last but a little while now!

In the afternoon, another group appears. Uniformed, more refined, calm - they are SA members. They rummage through the broken drawers. They methodically collect questionnaires and patient files. They put everything into grey folders. 
Three days later, books are burning in a square at Unter den Linden. (It is said that 40 thousand people are watching.) The orchestra plays folk songs and military marches, and everything is broadcast on radio. Nine students conduct the ceremony.

The first one ceremoniously approaches the fire. Tosses the book in and says:

Against class struggle and materialism, for the national community and an idealistic outlook, I commit Marx and Kautsky to the fire.

The second approaches the fire and says: Against decadence and moral decay, for discipline and morality in family and state, I commit Heinrich Mann, Ernst Glaeser, and Erich Kästner to the fire. Then a third, fourth, and fifth approaches the fire. The sixth, seventh, eighth, and ninth student.

And the dawn kept rising.

Like lightning, its song carried by the sap flows upwards from the roots, higher and higher. Through debris and dust, through shallow soil, it flows in the pine trunk through the pine body. Higher and higher, until it reaches the pine hand-branch. The soft needles of the sun touch the pine's fifth hand and melt within in it, spreading sunlight, yellow and red.

The tree hummed louder. The hand reached out, purred, and started to sing in a tree voice. And in the voice, these words could be heard:

\section{The Fifth Story: On How the Countess Dies}

One particularly beautiful day, the landlady suggests that Dina and she walk together to Scheitniger Park. The countess says in an offended tone that she needs time to dress. The landlady reassures her: You needn't hurry, Miss. We won't go anywhere without you.

But Dina is anxious. She starts speaking foreign languages. She has trouble fastening her belt: she ate a little too much for lunch today. She can't put on her dress on her own. The effort causes perspiration to appear on her forehead. The landlady's daughter has to reapply her makeup. Finally she is ready and they go into the street.

They walk through the park. There aren't many people there, and all of them are happy about that as Dina always attracts curious gazes. (And it is not proper to have so many eyes on oneself.)

Finally they stop at Schiller's monument. The landlady notices that the people around are looking at the countess, not the monument.

But Dina only looks at the monument. She avoids the people's gazes, and silently reads the inscription engraved in gilded letters on the plinth. Alle Menschen werder Brüder-All People Will Be Brothers. 
She grabs the landlady's daughter by the hand. She extends the other to her mother and laughs playfully.

And then she whispers to them: And here we are, like sisters we stand.

The fiancé has disappeared without a trace.

Dina has nervous pains again. She wants to call for the trusted doctor promised to prescribe her a morphine injection. The doctor was to come at nine, but he cannot come in person. Instead, he sends his assistant who asks how Dina is doing and gives her the injection. The countess goes to bed, but cannot fall asleep anyway. In the morning, she gets up feeling dizzy.

Another sunny day. Dina confides in the landlady that if the money she has been waiting for so long finally arrives, she will fly like a bird out of this unhappy city. The landlady asks her to wait several more days. To wait until she is stronger and healthier. Dina agrees. Helpless as a child, she is in no state to fly. Dinnertime comes.

The table hasn't been cleared yet when the doorbell suddenly rings. Ding dong.

The doctor is back. Dina complains to him that she hasn't slept all night, although the assistant injected her with a dose of morphine. And that she hasn't been able to sleep for a week. That her soul aches. The doctor is very sorry, he asks what is the matter. Dina says that the fiancé left her.

Yet when asked why, she says she doesn't know.

The doctor looks at her gently and asks: Perhaps you would like to confide in me?

The doctor insists on examining her, but the countess doesn't want to consent. She only allows her trusted doctor to examine her.

The table hasn't been cleared yet when the doorbell suddenly rings. Ding dong.

Here come two officials from the criminal division. They carry a medical examination order.

It turns out that when the fiancé disappeared without a trace last Sunday, he went to visit a friend and complained to him. After the conversation, the fiancé went to the police and informed on Dina. After that, he left.

The table hasn't been cleared yet when the doorbell suddenly rings. Ding ding. 
It's the police doctor. He carries a medical examination order. It turns out that the landlady informed on Dina. She once noticed, through half-closed door, that Dina was shaving in the bathroom. She thinks that the countess is a criminal, a spy.

The table hasn't been cleared yet when the doorbell suddenly rings. Ding dong.

A criminal commissioner arrives at the apartment. It was the fiancé who notified the police that Dina tried to break into his apartment. He fears her jealousy. The commissioner wants to talk to the landlady in private. He asks what the countess does with her time. The landlady says that they make paper roses. Appeased, the commissioner leaves.

The table hasn't been cleared yet when the doorbell suddenly rings. Ding dong.

Dina finally consents to the examination. She just wants to change in the dressing room. Suddenly, they hear a horrible moan. The moan turns into a scream, the countess is on the sofa, screaming and writhing in pain. The doctor asks the landlady if the countess has had such seizures before. She has, says the landlady, but never this bad.

Suddenly the countess falls to the carpet and makes no further sound. A final breath escapes from her breast, and then she doesn't breathe anymore. It turns out she has taken poison in the room, she is dying.

Dina finally consents to the examination. She just wants to change in the dressing room. She comes back after half a minute and with the words, "Here you go, doctor." She sits opposite him. Soon the poison starts working. Dina starts screaming and she falls down, seizing.

After a moment, she dies.

And the dawn kept rising.

Like lightning, its song carried by the sap flows upwards from the roots, higher and higher. Through debris and dust, through shallow soil, it flows in the pine trunk through the pine body. Higher and higher, until it reaches the pine hand-branch. The soft needles of the sun touch the pine's sixth hand and melt within in it, spreading sunlight, yellow and red.

The tree hummed louder. The hand reached out, purred, and started to sing in a tree voice. And in the voice, these words could be heard: 


\section{The Sixth Story: On a King and a Fisherman}

As a child, Dina has golden hair that falls into fine waves, as well as a predilection for rings, but the other children jeer at this and look askance at her.

When the countess was a child, she was particularly fond of her grandfather's old book, full of oriental stories. And in the book, she was fond of one particular fairytale. Completely different from the others.

It was a fairytale about a king and a fisherman.

There was once a king with black hair and dark eyes. His hair was soft and shiny like that of a newborn lamb. When you looked into his eyes, it was like looking into deep lakes. And his face was kindly, but the king never laughed.

Everyone loved the king, but the king loved nobody.

The mighty of the kingdom wanted a wife for him. But he knew he couldn't fulfill their wishes, even if they introduced him to the most beautiful princesses of all the neighboring countries. The stories of their charm only caused him to feel sad. He did not desire them. Instead, he looked for something that was absent.

One day he was walking along his sea shore when he noticed a young fisherman. The man extended his hand to him and took him on a voyage. The whole time, the fisherman looked at him in awe, and the young king saw himself in him. They returned to the royal palace together.

From then on, the king became joyful. His face was graced by a smile and he was no longer sad. But his happiness was short-lived. The hatred of the mighty of that kingdom reached the young boy who had the king's favor. They decided that the fisherman would bring misfortune to the country and agreed to murder him under the cover of night.

The king despaired and before a few months passed, he died of longing and regret. He was buried in the mausoleum he had had built for the murdered boy. And thus they lay, side by side, for several years. Eventually, even the proximity of their corpses disturbed the mighty of that kingdom. The fisherman's body was transferred to another grave.

And at this point the sixth hand of the pine had sung the final story.

And the day came. 
Sunlight flooded the forest. The whole hill basked in the light, while the fresh breeze rubbed every leaf, every stem, every blade of glass, and every leafy hand was wrapped in gold. Quivering in the wind, the trees took on a bluish tint. Squirrels jumped happily around the branches. The woodpeckers pecked and the cuckoo called out fortunes joyfully.

The fragile bark of the pines, protruding on the gnarls, pearled in the light of the dawn. And the milky-pink trunks of the ever cool birches would grow whiter, like snow, or pinker, like stork legs.

And then, in this shameless light of the day, something happened that should only happen in the dark shame of the night. Something happened that doesn't always happen, and not to everyone.

The pine gathered herself and shook inwardly. She swayed proudly at the roots, pulling them out, one by one, her six roots, her six tree legs, from the hill of piled up rubble.

First she pulls out one leg. Higher, higher.

Then. She pulls out a second leg. Higher, higher.

Then the third one.

Then the fourth, then the fifth one.

And when the sixth leg leaves the ground, when the entire broom of the roots unroots itself from the grass. Then the pine mounts herself like a flying broomstick, and takes off in the air. She prances around the skies with her branches falling loose in the wind. Quickly, she flies down the slope, lower and lower, to the golden city, fluttering her carpet of pine needles, swishing her crown like a horse's tail.

She flies to tell the people her six stories.

On reaching the city, she alights at a crossroads and waits.

A child is walking to school with a book under his arm. The pine stops in front of him and starts talking. The child reaches in his pocket, takes out a penknife, cuts into the pine and scratches her legs. The pine curls up at the brink of the road, creaking and howling pitifully.

She raises her six hands to the sun and starts complaining.

And the sun says: Why didn't you go to a human?

Surprised, the pine replies: Who was he, if not a human?

He will only become one in the future - the sun says.

The pine nods. She runs, stops at the crossroads again and waits. There comes a hunter with a rifle in his hand. As the pine approaches, he aims and shoots. 
The pine feels as if half her trunk's been torn away. In the crossroads there needles and sawdust everywhere. Amber drops pour out in a sticky stream, and the resinous smell of the wound mixes with the air. The pine hums and shakes in pain, starts running, and jumps into a ditch.

She raises her six hands to the sun and starts complaining.

Oh, sun, sun, I see you are lying to me... You told me to look for a human. He was walking down the road with a shining stick in his hand. He stood at a distance, put the stick to his face and spat! And something prickled my trunk so bad that I'm barely alive for the pain.

The sun responds. Serves you right... Should have gone to a human.

Surprised, the pine replies: Who was he, if not a human?

He was one in the past - the sun says.

The pine hums, nods, goes to the crossroads and waits. A woman comes. The pine stands in front of her and starts talking.

I will gladly listen to your stories, pine, the woman says. Wait a moment, and I will quickly bring blankets to sit on from the house, milk to drink. We will sit together, hum together, drink the milk. We will twaddle, we will tell fairytales.

The pine squats happily on the hill and watches the woman going away. Soon she sees the woman with a huge weight under her skirts. She is all bent down, carrying it. Suddenly two huge dogs jump out from under the dress. They throw themselves on the pine and spread her on the ground, rolling it all around.

Barely does the poor pine manage to get away and hide behind the corner of a nearby house, so bitten that she nurses her wounds with resinous tears until noon.

The noon has come. She raises her six hands to the sun and starts complaining.

Who can be blamed, the sun says, that you cannot find a human.

That was not a human? The pine, saddened, wonders.

That, my pine, was a woman, the sun says. And you must know that although the world is full of people, it's difficult to find a human.

The pine returns to the hill of piled up rubble. With a tucked tail of sad hands. With a dolorous sadness of roots-legs. Carried on the wings of the wind. Not touching a foot to the ground, she flies like a wild pigeon. 
She turns herself upside down, lays the crown of six branches on the grass, and exposes her six roots to the sun-sky. Her hands burrow into the soil, lower and lower. Through a multitude of debris. Through red bricks, concrete, dust, and ceiling beams. Through shattered tombstones of marble, terrazzo, granite. Household trash which fell apart together with the demolished houses. All those human belongings which no-one grabbed when forced to run. Whatever people couldn't take on their backs, in small carts, grab, take, carry to a new home. And paving stones taken from a field long ago, crumbs of churches, a synagogue, a chapel. Even fragments of monuments, metals, old nails and rust.

And the pine hands penetrate all this as they spread outwards. When a root meets a piece of debris, it touches its song, embraces it, and caresses it in a debris embrace.

And from then on the pine will not sing any more stories.

And everything is different than before, although it may seem that nothing has changed.

Acknowledgements: While writing the above text, I relied on Mathias Foit's analyses of the German sources.

Translation: Ewa Bodal. Editing: Dominika Ferens.

[For photographic documentation of the performance, see pp. 72, 75-79, 97-101.]

\section{Works Cited}

Beachy, Robert (2014), Gay Berlin: Birthplace of Modern Identity, New York, Alfred A. Knopf.

"Berliner Pupenjungen" (2014), Folk song originally published in 1905. Reprinted in: Robert Beachy, Gay Berlin: Birthplace of Modern Identity, New York, Alfred A. Knopf.

Foit, Mathias (2019), "'Męska narzeczona' z Wrocławia", Replika, 80: 28-30.

Hirschfeld, Magnus (1904), Berlins Drittes Geschlecht, Berlin, Verlag von Hermann Seemann Nachfolger.

_- (1910), Die Transvestiten, Berlin, Medicinischer Verlag.

___ (1914), Die Homosexualität des Mannes und des Weibes, Berlin, Verlag Louis Marcus.

Homann, Walter (2010), Tagebuch einer männlichen Braut, $2^{\text {nd }}$ edition, Hamburg, Männerschwarm Verlag.

Leśmian, Bolesław (1956a), "Podlasiak", Klechdy Polskie, London, Katolicki Ośrodek Wydawniczy Veritas.

—_. (1956b), "Wiedźma", Klechdy Polskie, London, Katolicki Ośrodek Wydawniczy Veritas.

Lewy, Guenter (2016), Harmful and Undesirable: Book Censorship in Nazi Germany, New York, Oxford University Press.

Monatsbericht des Wissenschaftlich-Humanitären Komitees (1907), Vol. 6, Berlin. 
Neugebauer, Franz von (1908), Hermaphroditismus beim Menschen, Leipzig, Verlag von Werner Klinkhardt.

"O wilku i jego przygodach" (1902), Starożytne podania i powieści ludowe z różnych pisarzy zebrane, Poznań, Fr. Chocieszyński.

"Porwany wichrem" (1902), Starożytne podania i powieści ludowe z różnych pisarzy zebrane, Poznań, Fr. Chocieszyński.

"The Servants' Song" (1991), The Beauty and the Beast, Walt Disney Studios. Song cut from the original version of the film and restored in the 2002 version.

Römer, Marie (1907), Mein Zimmerherr. Selbsterlebtes, Breslau, H. Fleischmann-Verlag.

Wessel, Horst (1929), "Horst Wessel Lied", Translation based on the English translation in JeanDenis Lepage, Hitler's Stormtroopers: The SA, The Nazis' Brownshirts, 1922-1945, Frontline Books, 2016, and an anonymous Polish translation from the 1960s, https://pl.wikipedia.org/wiki/Horst-Wessel-Lied

Zmorski, Roman (1852), "O dziadowym synu”, Podania i baśni ludu w Mazowszu, Wrocław, Zygmunt Schletter. (1891), Baśń o Sobotniej Górze z podań śląkich, Warszawa, Józef Jeżyński. 